\title{
Development as Struggle: Confronting the Reality of Power in Palestine
}

ADAM HANIEH

The occupied Palestinian territories (oPt) are a major recipient of global aid flows, ostensibly aimed at improving development outcomes for the Palestinian population. This article presents a critical analysis of the ways that development is being conceived and practiced by major actors in the oPt. By analyzing different conceptions of power, the article examines how dominant approaches to development hide the ongoing reality of Israeli settler colonialism by dehistoricizing Zionism and its project; incorporating the structures of Israeli occupation into official Palestinian development strategy; and promoting an economic perspective that views development as an objective and disinterested process operating above (and outside) power relations. After considering some of the ramifications of current approaches to development, the article concludes with brief remarks on how this critique can help to reframe and articulate an alternative strategy.

\section{Palestinian Aid Dependency and Israeli Settler Colonialism}

The OcCupied Palestinian terRItories are one of the most aid-dependent regions of the world; per capita foreign aid reached $\$ 579$ in 2014 , a level exceeded at a global level by only a handful of small island states. ${ }^{1}$ Alongside the Palestinian Authority (PA), thousands of institutions receiving and distributing this aid span the gamut from local and international nongovernmental organizations (NGOs) to multilateral agencies such as the World Bank and the United Nations Development Programme (UNDP), as well as bilateral funders such as the United States Agency for International Development (USAID) and the United Kingdom's Department for International Development (DFID). ${ }^{2}$ In addition to providing direct funding, these institutions also employ a great number of Palestinians, and are thus a central component of the Palestinian economy in their own right. $^{3}$

Still, aid activities have proven largely ineffective, regardless of their high levels and of the prominence of the question of development in the oPt, both of which have been massively disproportionate when considered in an international comparative perspective. The Canadian International Development Agency (CIDA) notes, for example, "Despite large aid flows [to the oPt],

Journal of Palestine Studies Vol. XLV, No. 4 (Summer 2016), p. 32, ISSN: 0377-919X; electronic ISSN: 1533-8614. () 2016 by the Institute for Palestine Studies. All rights reserved. Please direct all requests for permission to photocopy or reproduce article content through the University of California Press's Reprints and Permissions web page, http://www.ucpress.edu/journals.php?p=reprints. DOI: 10.1525/jps.2016.45.4.32. 
progress toward the Millennium Development Goals is negligible and in some cases regressing, especially with respect to poverty, hunger, health, education, and the environment."4 According to the most recent Palestinian Central Bureau of Statistics figures, more than one quarter of the oPt population lived under the poverty line in 2011, with the figure for Gaza reaching close to 40 percent. ${ }^{5}$ As development indicators worsen, some of those involved in the aid industry within Palestinian society have transformed into a new elite aligned with globalized networks of external aid flows. ${ }^{6}$ Furthermore, the billions of expended aid dollars have led to an increase in Israel's effective control over the Palestinian population and not to an appreciable lessening of Israeli suzerainty despite the establishment of the PA and the vast amount of foreign technical and financial support allocated for its institution-building. Thus, both the intense amounts of aid and attention to development that have been directed at the oPt have resulted in a failure of development, a circumstance better described by Sara Roy as "de-development."7

This article contends that the concept of development as understood by key actors in the oPt is a major reason for that failure. International organizations-and many local Palestinian NGOsproject a view of development divorced from the power relations at play under Israeli settler colonialism. Advocates of this view conceive development as a neutral technocratic process whose success hinges on the right technical and financial support from donors, a negotiated reduction in Israeli-imposed restrictions, and the implementation of appropriate state-building policies on the part of the PA. This mainstream perspective considers development in a vacuum, unaffected by power relations, as a positive-sum game. In this regard, it is the lack of coordination between stakeholders, and not the power relations completely structured around Israel's ongoing colonization of the area, that stands as a major obstacle to development. As a result, the dominant development framework obfuscates, and thereby strengthens, the reality of Israeli settler colonialism in the oPt.

In exploring the ideas outlined above, this article begins by tracing different conceptions of power in the settler-colonial context and counterposing these to the notion of empowerment prevalent in Palestinian development discourse. The article then examines how development approaches hide the ongoing reality of Israeli settler-colonial power by: dehistoricizing Zionism and its project; incorporating the structures of occupation into official Palestinian development strategy; and foisting economic neoliberalism on the PA, wherein development is an objective and disinterested process operating above (and outside) power relations. After considering some of the ramifications of current approaches to development, the article concludes with brief remarks on how this critique can help to reframe and articulate an alternative strategy.

\section{Empowerment without Power}

NGO and multilateral projects in the oPt commonly headline empowerment as a key development goal. The World Bank openly urges "citizen empowerment" that it cites as a major prerequisite for development across the Middle East, ${ }^{8}$ providing tens of millions of dollars in funding to projects that operationalize the idea. ${ }^{9}$ Local and international NGOs echo this theme both in their project titles and strategy documents. For instance, the Palestinian Businesswomen's 
Association, a microfinance institution, speaks of "the need for economic empowerment of all segments of society ... with a special need to focus on women and include women actively in the process." ${ }^{10}$ The U.S. Department of State, through its Middle East Partnership Initiative (MEPI), funds a Leadership Empowerment Program that has provided \$2.2 million in grants to strengthen "targeted communities' trust and confidence in local leaders and enhanc[e] public participation among marginalized sectors." 11 The United Nations Children's Fund (UNICEF) and CIDA fund children's municipal councils in the West Bank to "give children a sense of empowerment." 12 USAID funds Palestinian NGOs "to empower Palestinian youth and the adults who serve them, so that both groups can become strong local leaders and change-makers."13

This promotion of a seemingly activist orientation typifies a broader global shift in development practice. Since the 1980s, governmental and multilateral donors have gradually embraced the notion of empowerment, along with others such as decentralization, governance, and participation, as central to development in the Global South. Consequently, as scholars Giles Mohan and Kristian Stokke note, the language used by critics of mainstream development practices has been appropriated and thus partially neutralized. Discursively, there is "a high level of agreement between actors and institutions of the 'new' Left and those of the 'new' Right." 14 Nowhere is this more evident than in how the World Bank has attempted to shift its image from the predatory, neoliberal lender that garnered such intense criticism through the 1980s and 1990s to that of a "pro-poor" institution "working for a world free of poverty," as the current slogan of the bank proudly claims on its website. ${ }^{15}$

In reality, however, this discursive shift does not mark a substantive break with earlier policies of neoliberal structural adjustment. Instead, the shift makes those policies more palatable to the general public while helping to facilitate their implementation by discursively reconfiguring the role of the state within the development process. Most importantly, the championing of empowerment-and related themes such as good governance and decentralization-places the emphasis of development on the choices of the individual engaged in the market, as exemplified by the proliferation of microfinance schemes. In the same vein, it emphasizes individuals from an allegedly homogenous community or civil society while abstracting any internal power differences within the group. We consequently see "the emergence of 'the local' as the site of empowerment and hence as a locus of knowledge generation and development intervention."16

This shift to localism sets the individual (or the community) in opposition to an inherently predatory state, making it easier to legitimate calls to disable state interventions in the market. Any increase of state spending for social programs, for example, can be portrayed as inefficient and as an affront to the freedom of markets and individuals. Limiting democracy to the political sphere and expanding the notion of freedom to include markets veil the power relations inherent to capitalism. Such trends undermine the ability of states to determine the use, ownership, and distribution of their economic resources because any form of democratic state-led control of the economy would, by definition, need to restrict the activities of the private sector. As the World Bank governance indicators confirm, restrictions can be violations of good governance. ${ }^{17}$ "Tempered by current emphasis on dismantling welfare, exerting fiscal discipline, and privatizing state services, the neoliberally imagined empowerment logic seeks to enable grassroots actors, and especially women, to fulfill their own needs through market mechanisms instead of relying on 
state largesse," as Aradhana Sharma argues in an analysis of gender-focused programs in India. ${ }^{18}$ To consider NGOs as the primary agents of development is to support the move toward a marketdriven, neoliberal developmental model. ${ }^{19}$ In a critique of mainstream development policy, Andrea Cornwall and Karen Brock sum up this view as follows: "The fine-sounding words that are used in development policies do more than provide a sense of direction: they lend the legitimacy that development actors need to justify their interventions." ${ }^{\text {"20 }}$

A second, related feature of the focus on empowerment, community involvement, and good governance has been an increasing reluctance to recognize and discuss the various dimensions of structural power that shape all developmental processes in the South. The focus on the local downplays the totality of social relations in which all communities are necessarily situated. Development has become a problem internal to the individual (or the community), which can best be solved through the mysterious mantra of empowerment. Underdevelopment thus becomes the fault of the oppressed themselves, not a situation primarily conditioned by the prevailing structures of power; the oppressed must rise to the challenge of unlocking an innate potential for development. Of course, this is not to deny that people do possess the capacity to resist and challenge their oppression-this is perhaps nowhere better illustrated than in Palestine. Despite attempts to downplay them, power structures are necessarily inherent to all development processes, and the primary challenge should be to overturn them and release their constraints on social potential rather than veil them. Disregarding the structures of power actually serves to reinforce and maintain the existing social order, just as upholding them would, and it hides the very practice of power itself.

Empowerment makes no sense unless it is in confrontation and conflict with systemic power; however, this is not the approach of most development work in the oPt, which tends to ignore the broader question of power completely. Usually, development projects follow a model that attempts to coexist with the structural determinants of Israeli colonialism. In the worst examples, these development models actually attempt to incorporate Israeli colonialism into the very practice of development itself. As Mohan and Stokke observe, many development practices in the Global South share this approach, based upon what they call "a harmony model of power" in which "power resides with individual members of a community and can increase with the successful pursuit of individual and collective goals. This implies that the empowerment of the powerless could be achieved within the existing social order without any significant negative effects upon the power of the powerful." ${ }^{21}$ As a result, development practice tends to "aim at improving those at the margins within the existing systems without really questioning the unequal power dynamics that create inequality in the first place." 22

The remainder of this paper concerns selected features of Israeli settler colonialism and its impact on development processes. Before moving to this discussion, however, it is necessary to first articulate the concept of power. Drawing upon the vast development literature that addresses the concept, this article outlines and utilizes three basic, interconnected meanings of power. ${ }^{23}$ The first is the standard understanding of power as "the ability to dominate." ${ }^{24}$ In this sense, power contains a sense of compulsion, forcing people to act in a particular fashion. This might result from military superiority, control of economic resources and borders, or restrictions on movement of goods and people. 
A second meaning conceives of power in an indirect sense. People may act in particular ways not because of a physical threat or compulsion but because they believe that it is in their best interest to do so or because they fail to see any effective alternatives. In this sense, their lack of "ability to see and conceive alternatives" 25 is a form of psychological domination. People follow a direction because they mistakenly think that no other possibilities exist. ${ }^{26}$ As discussed below, this conception of power is closely linked to interpretations of the past and forms of historical narrative and national identity.

In a closely related sense, the third meaning of power conveys the feelings "of self-worth and selfesteem that people hold in themselves." ${ }^{27}$ These feelings may occur at the individual level and across different social groups. Like the first two types of power, here too there is a psychological dimension: without feelings of self-worth and self-esteem-and this, it is important to emphasize, does not refer solely to an individual sense but very much a collective spirit-it becomes difficult to believe in, conceive of, and struggle for different alternatives. Among the distinguishing effects of colonial domination, as Frantz Fanon noted decades ago, is its ability to produce a "people in whose soul an inferiority complex has been created." 28

Palestinians contend with Israeli power in all three forms in their attempts to understand and counteract the effects of Israeli colonialism in the oPt. The remainder of this paper discusses how these forms of power operate-and are hidden-within the dominant approach to development.

\section{Fragmentation and Dehistoricization}

For over six decades, Israeli settler colonialism has divided and fractured the Palestinian people. The different waves of twentieth century colonization in Palestine have deliberately aimed to splinter Palestinians into a patchwork of fragmented, dispersed territories that evolve as distinct social formations. ${ }^{29}$ The various categories used to describe the Palestinian people speak to that proposition: Palestinian refugees; Palestinians who remained on their land in 1948 and later became Israeli citizens (the Palestinian citizens of Israel or PCI); the fragmentation of the West Bank into isolated cantons; the separation of the West Bank and Gaza Strip; and now the apparent division of East Jerusalem from the West Bank. Palestinians living in these geographical zones constitute the Palestinian nation, but Zionist colonization since before 1948 has been steadily eroding this unity. The ways in which Israeli power operates in the oPt is one element of the broader Zionist project, and thus a theorization and understanding of the logic of fragmentation must be viewed as essential to mapping the nature of colonial strategy in the oPt. Similarly, the logic of fragmentation must also inform our conception and implementation of development in the oPt. Fragmentation is not solely a spatial process; it also occurs through temporal disruption. In other words, Israeli power relies not only on the geographical fragmentation of the Palestinian nation but on assaulting its very history, dehistoricizing the Palestinian experience and reducing it to a recent narrative that accepts the results of fragmentation as de facto and permanent. ${ }^{30}$ Temporal disruption makes it possible to speak of Gazans, for example, with no reference to how this category itself was constructed through the forcible fragmentation of the Palestinian people as a whole, first in 1948 and then through the separation of the West Bank and Gaza Strip. Because 
these categories are accepted as givens and become the legitimate (and sole) focus of development intervention, they continue to reproduce. In this light, an uncritical and dehistoricized developmental strategy lends materiality to Israeli power and sustains fragmentation.

This process of fragmentation-both its spatial and temporal aspects-relies on the first form of power as forceful compulsion described above. Israel bars Palestinian refugees from returning to their land, separates the West Bank and Gaza Strip from one another, places restrictions on the movement of PCI into the oPt, and completely controls movement in the West Bank itself. ${ }^{31}$ But fragmentation is also reflected in the sense of "power to see and conceive options for change." 32 The development discourse has fully internalized the fragmentation of the Palestinian people. With few notable exceptions, NGOs in the oPt operate as though the Palestinian population consists entirely of those people living in the West Bank and Gaza Strip (and, increasingly, in only one of these areas). It is rare to find developmental work that openly confronts and rejects this process of fragmentation, conceiving of the Palestinian people in their unity across the various constructed borders. This is particularly pertinent in the case of projects that link with the PCI, whose Palestinian-Arab identity the Israeli state has long sought to reframe as an ethnic minority.

For many Palestinians, this process of fragmentation generates a narrowing of political vision and imagination, a manifestation of the second and third forms of power discussed above. Fragmentation weakens collective identity as the social horizon contracts to the confined borders of those cantons in which people happen to live. Ramallah is a striking example of this: as the headquarters of PA ministries, international donors, and local NGOs, it has taken on a life of its own. Circumscribed within these borders, people find it difficult to conceive of alternative paths of action. This narrowing vision becomes normalized, sustaining the operational practice of NGOs and other development agencies while further reinforcing social disunity and torpor vis-à-vis a collective political project.

\section{Absenting Power, Incorporating the Occupation}

In the West Bank and Gaza Strip, the process of fragmentation has unfolded thanks to Israel's strategy of achieving control over the Palestinian population without the attendant costs of a direct military presence in Palestinian towns and villages. ${ }^{33}$ This is not new, for the 1967 Allon Plan explicitly called for this method of domination in the West Bank. It is striking how various maps discussing final status issues today reflect the projected borders of the Allon Plan. ${ }^{34}$ Through the 1990s, this system of control developed into a complex bureaucratic structure of permits, checkpoints, and zoning laws to control the movement of people and goods between the patchwork of territories in the West Bank (with Gaza constituting its own self-contained fragment). The system of military orders that has governed Palestinian life since 1967 continues to exist. Moreover, Israel controls electricity, water, cellular communications, and even the Internet; this infrastructure may be marketed by Palestinian companies, but in the final analysis it is ultimately supplied and controlled by Israel. ${ }^{35}$ These are all illustrations of the first form of power-the ability to compel Palestinians to act in particular ways. Despite the apparent veneer of Palestinian autonomy, the Oslo process did not lead to a lessening of Israeli power but rather to a 
change in its form. In the post-Oslo years, Israel has sharpened and rearticulated its control; as a consequence, Palestinian development is today subject to Israeli power more than at any point in history.

One of the most important forms of this control is the economic system that has developed under colonization. The Palestinian economy is fundamentally structured by its dependency on Israel. Through the 1970s and 1980s, this dependency grew as a result of military orders that prevented Palestinian industrial and agricultural development and yoked the pool of cheap Palestinian labor to the Israeli economy. ${ }^{36}$ Today, the system controls essential goods entering the oPt, multiplying the profits of Israel's largest companies in myriad ways. First, with the oPt a key market for Israeli goods and Palestinian consumption largely funded through external capital flows, much of the foreign aid essentially flows to Israeli firms. ${ }^{37}$ Second, the prevalent forms of development across the West Bank today-such as new buildings, cafés, housing complexes, malls, and industrial zones-primarily benefit Israeli business and only a meager portion of Palestinian society, a point that will be discussed further below. Additional aspects of this economic control include the absence of a Palestinian currency, which leaves the monetary system in the oPt beholden to Israel's central bank and results in severe inflation that, again, benefits Israeli companies but drains wealth from the Palestinian population. ${ }^{38}$

Any analysis of development in the oPt must incorporate such structural considerations. To speak of development, in particular economic policy-making, without starting from the fact that the Palestinian economy operates essentially as a dependent adjunct to Israel, is to conceal the exploitative relationship at the core of Israel's occupation. Disregard for such considerations runs almost unquestioned in all the major multilateral agency reports on Palestinian economic development. The World Bank, for example, devotes thousands of pages of analysis to outlining the necessary steps for Palestinian state-building. It does so by positing policy choices by the PA and Israel as complementary rather than viewing settler colonialism as a form of power that structures all aspects of Palestinian life. While multilateral agencies encourage Israel to tinker with aspects of its policy so as to enable effective PA operations, Israel is conceptualized as playing a potentially positive role in Palestinian development. A 2010 World Bank report states, for example:

The twin pillars of sustainable growth and robust institutions for the future Palestinian state must be a joint undertaking of the PA, GoI [Government of Israel], as well as the international community. As this report has laid out, all three have played their role in the recent growth that has taken place in WB\&G [West Bank and Gaza]: the GoI by easing movement and access restrictions, and the donors by funding the PA's spending. All three actors continue to have important roles to play for this recent growth to transform into sustainable growth, and for the sustainable growth to support further progress for robust institution-building. For the GoI, further actions to improve the conditions on the ground and allow a real take-off in private sector development are necessary. For the PA, a continuation on the path of improving the business environment is key, as are the measures it is taking to strengthen its fiscal position and thereby bolster its institutions. And for the donor community, continued generosity is of the essence to consolidate the substantial gains made by the PA and allow it to reduce its reliance on external support without compromising basic service delivery to the Palestinian population. ${ }^{39}$ 
This World Bank statement demonstrates how the development discourse in the oPt effaces Israeli power. From the bank's perspective, the joint efforts of the Israeli government, PA, and the international community can solve the problem of economic development. All three parties must contribute to this process: Israel, by easing movement and access restrictions, the PA, by building the right institutional framework, and donors, by funding the overall process. ${ }^{40}$ These three activities aim primarily at growing the Palestinian private sector, purportedly leading to a sustainable economic future for the Palestinian population in these areas, an agenda rooted in the World Bank's dominant neoliberal outlook. Within this perspective, there are no structural relations of exploitation and domination between Israel and the Palestinian population in the oPt. In a similar fashion, the term international community also empties the global economy of its sharply hierarchical power relations, presenting it as a neutral, homogenous, and disinterested body concerned simply with the welfare of the Palestinian people.

Ignoring these relations of power means that Israeli colonialism becomes part of the process of Palestinian development itself. When the World Bank, for example, asks the PA "to work alongside Israeli Customs [at the Allenby Bridge] and practice actual customs border procedures and gain needed experience," ${ }^{41}$ it reframes Israel's control over borders as a technical skill rather than an integral feature of how the occupation actually works. Perhaps the starkest illustration of this discursive shift is the World Bank's funding of Israeli checkpoints inside the separation wall, which normalizes the architecture of Israeli settler colonialism in the name of speeding up trade. ${ }^{42}$

Arguments justifying this approach as a way to work with the status quo in order to improve the day-to-day conditions of Palestinians on the ground only serve to reinforce and strengthen that same Israeli power that has now been woven into the process of development. Depicting Israel as a neutral partner or merely another stakeholder makes it more difficult to confront Israeli settler colonialism in any meaningful fashion because the structures of the occupation become increasingly entangled with Palestinian development itself. This may certainly entail a change in the form of Israel's control-a shift from direct military presence toward a greater reliance on bureaucratic-juridicaleconomic frameworks of control-but it does not fundamentally alter the relationship that exists between Israel and Palestinian society in the oPt.

\section{Neoliberalism and the Neutrality of Markets}

The conception of development described above reflects, and has been reinforced by, the neoliberal economic program embraced by the PA. Neoliberalism is a set of policies that first rose to prominence in the 1980s and now dominates official development thinking at the global level. ${ }^{43}$ Its overall approach is to ascribe the problems of development in the Global South to the supposed weakness of the private sector and the rent-seeking of state officials. As a result, neoliberalism internalizes the causes of underdevelopment within individual societies in the South and posits a non-exploitative world market in which flows of capital and goods between countries are mutually beneficial (succinctly expressed, for example, in the economic doctrine of comparative advantage). ${ }^{44}$ According to the neoliberal worldview, the solution to the South's development problems is to open markets to the outside world, lift restrictions on investment in 
key sectors of the economy, liberalize ownership laws, end subsidies to the poor for food and other necessities, deregulate labor markets, and increase market competition. ${ }^{45}$ By allowing unfettered markets to operate freely, this view argues, the private sector will be the key engine of growth and this harnessing of entrepreneurial initiative will lead to the creation of jobs and prosperity.

The economic framework adopted by the PA has fully embraced this logic as evidenced in its 2007 Palestinian Reform and Development Program (PRDP), and in subsequent national development strategies, whose goal is to create a "diversified and thriving free market economy led by a pioneering private sector that is in harmony with the Arab world, [and] is open to regional and global markets." 46 In order to achieve this goal, the PA has pursued a program of fiscal austerity, a development strategy based on tax-free industrial zones and conspicuous private-sector projects, and closer security cooperation with Israel. As these policies have been critiqued elsewhere, ${ }^{47}$ the pertinent issue here is the manner in which the PA's broader economic strategy posits the neutrality of international financial institutions (IFIs) and, most importantly, of markets themselves.

In the former case, IFIs present themselves as neutral, technocratic experts on economic issues, which aim simply to provide sound advice on matters of economic policy and institutional governance. ${ }^{48}$ In practice, however, key institutions such as the World Bank and the International Monetary Fund (IMF) have been promoting neoliberalism at a global level-enforcing this approach through debt and structural adjustment programs. In the case of Palestine, the power of the IFIs is evinced in the fact that donor funding to the PA runs through a trust fund headquartered in Washington and managed by the World Bank, ${ }^{49}$ with the disbursement of funds contingent on the PRDP's progress. Today, that conditionality has extended to all international lending to the PA. In this manner, IFIs directly shape Palestinian economic development and understanding Palestinian development processes in the oPt thus requires a full interrogation of the power relations inherent to institutions such as the World Bank as well as the content of the neoliberal agenda itself. ${ }^{50}$ On the question of trade, the World Bank writes,

As a small open economy, the future Palestinian state will depend upon increasing trade. . . Increasing trade and integration into the international markets will provide consumers access to a wider range of products at lower prices, while producers will benefit from higher prices found on the world market. ... In addition, becoming competitive on the export market will force Palestinian producers to improve their productivity, thereby increasing employment, raising wages, and lowering poverty ... [trade in intermediate inputs] provides an important opportunity for a future Palestinian state, located as it is close to both the highly developed Israeli and European economies. ${ }^{51}$

This perspective is remarkable for its presumption that the unhindered operation of the market will produce the best possible outcome (increasing employment, higher wages, lowered poverty, and so forth). ${ }^{52}$ It exemplifies the "harmony model of power" wherein all participants, regardless of wealth or position within the structure of occupation, benefit from the increasing spread of market relations. ${ }^{53}$ Power is disappeared, and so too is the acknowledgment that those who wield it have the ability to shape outcomes that serve their own interests. 
Indeed, the much more likely outcome of the World Bank scenario-precisely because of Palestinian proximity to "the highly developed Israeli and European economies"- is the development of a low-wage, highly exploited workforce as a prerequisite for "becoming competitive on the export market" and "improv[ing] productivity." 54 Impoverishment of the majority alongside the enrichment of a tiny layer of Palestinian society that acts as the interlocutor with Israeli and foreign capital, is the end point that will, as Raja Khalidi and Sobhi Samour put it, "perpetuate Palestinian dependence on Israel and allow personal prosperity for some but communal impoverishment for all." 55

The key point here is that market neutrality benefits those who wield power-which, in the case of Palestine, inevitably means Israeli companies and a narrow layer of the Palestinian elite-and worsens the living standards of the vast majority. Recent poverty statistics point to growing inequality within Palestinian society and confirm this prognosis. ${ }^{56}$ It is necessary, therefore, to look beyond simple aggregate measures of development-such as gross domestic product growth - and instead probe questions of inequality and the distribution of wealth in order to determine who are truly the winners and losers of development processes.

One final aspect of neoliberalism is important to highlight: the massive expansion of financial markets in recent decades. According to the Palestinian Monetary Authority, the amount of money disbursed in loans to individuals residing in the West Bank and Gaza Strip more than doubled from $\$ 1$ billion in 2010 to $\$ 2.2$ billion by end-2015. ${ }^{57}$ Much of this credit is used toward residential real estate, automobile purchases, and consumer loans. In these three sectors alone, loan amounts extended to individuals grew by a remarkable 160 percent between 2011 and 2015 (reaching $\$ 869.4$ million). ${ }^{58}$ These figures stand in sharp contrast to the widespread deterioration in living standards in the oPt: in 2014, unemployment stood at 26.9 percent of the workforce (in a context where labor force participation is only 45.8 percent), and more than one quarter of the population was living under the poverty line. ${ }^{59}$ Given such figures, the expansion of financial markets is a good indication of the extent to which apparent development across the West Bank has been debt-fueled: the Ramallah urban landscape has transformed strikingly over the past few years, with a proliferation of billboards promoting banks and credit as for the purchase of largeticket items such as houses, cars, and other consumer goods.

The growth of finance is an integral feature of neoliberalism-described in the nomenclature of IFIs as "financial deepening" - and it plays a significant role in the articulation of power in the oPt. ${ }^{60}$ As numerous scholars have noted, the spread of individual and household debt has a profound impact on social behavior and the patterns of everyday life within contemporary capitalism. ${ }^{61}$ Individuals increasingly depend upon financial markets to meet their daily needs while the management of various forms of personal risk-such as insurance, medical needs, social security, and pensions-becomes subject to mediation by financial institutions. ${ }^{62}$ This fits neatly with the decline in provision of social services under neoliberalism. All of these aspects of financialization are closely connected to the second and third forms of power noted earlier: a difficulty in conceiving alternative options and an erosion of the self-confidence that people hold in themselves. Indeed, some authors have pointed to how financial markets may corrode forms of collective struggle and social solidarity, as individuals become primarily concerned with conditions of stability and their perceived ability to meet future financial payments. ${ }^{63}$ 
Such an argument is not meant to convey pessimism about the possibility for collective struggle. Rather, it is a call to register the ways in which the neoliberalization (and financialization) of the economy can generate a tendency for people to seek individual solutions to what are fundamentally social problems. At the same time, the effects of neoliberalism also point to new terrains of struggle. Immanent to finance-led neoliberalism is a dire imbalance in the patterns and forms of accumulation between different sectors of the population and geographic areas; thus, neoliberalism also produces sharper class contradictions within Palestinian society. Acknowledging such contradictions is necessary to a proper assessment of the possibilities for development and the capacity for injecting a dynamic of struggle into the process.

From this perspective, development in the oPt is always interlaced with forms of power that structure the capacity of Palestinians to resist, which on a psychological level affect how people behave and think about themselves and their relationship to society. As a result, it is incumbent upon us to interrogate how power operates, how it reproduces itself, and what can be done to challenge it. The insistence on the neutrality of development and the belief that it is not there are both a manifestation of the existence of such power. To treat development simply as a technocratic and apolitical process is to reinforce and support the dominant forms of power. Thus, it is urgent to expose and reveal power-to think more intentionally about how power relations are intrinsic to all development practice within the oPt.

How can development be conceived not as a question of growth, governance, or participation but rather as a form of resistance and struggle? First, if the essence of Israeli settler colonialism is the ongoing attempt to fragment and dehistoricize the Palestinian people, then reframing development requires asserting the unity of the people as a whole and building connections across borders, whether physical and mental, constructed by colonization. In other words, it is necessary to reject any narrowing of the Palestinian question to simply the West Bank and Gaza Strip. Israeli colonization affects all segments of Palestinian society, including those individuals who may now hold Israeli citizenship, Palestinian refugees, as well as the Diaspora. Narrowing the parameters to the West Bank and Gaza Strip, or to the post-Oslo period, internalizes and consolidates the results of Israeli settler colonialism. How many development initiatives, for example, look at strengthening connections between PCIs and those living in the West Bank or in the Diaspora? Of course, there are practical problems involved, because legal and administrative measures actualize fragmentation, but the point is that the power of colonialism operates through this process of fragmentation.

Second, resistance to power necessitates a rejection of efforts to enforce its legitimacy. Development as struggle means adopting a framework that refuses to normalize colonial power, as exemplified by the Boycott, Divestment and Sanctions (BDS) movement, which rejects any joint activities with Israeli state institutions or projects that normalize colonial power and present the situation of Palestinians as simply a conflict between two parties. The success of the BDS movement can be traced to its ability to highlight and expose the reality of power and its refusal to legitimize and normalize it. To say "no" can be a tremendously powerful act. This notion of antinormalization is not a recent invention or foreign import but has a played a prominent role in the history of the Palestinian struggle for decades. 
Finally, the neoliberal development strategy has generated increasingly sharp inequalities within Palestinian society itself. Neoliberalism atomizes and fragments Palestinian society, making collective struggle more difficult in an environment of individualized consumption. A society that prioritizes such a development trajectory weakens its resilience and capacities. For this reason, the internal struggle against neoliberalism is inextricably connected to the broader struggle against Israeli power. Practically, this implies an emphasis on defending and extending social rights and rejecting the myth of market neutrality. Sociologist Jamil Hilal stresses that "empowering of Palestinians in the WBGS [West Bank and Gaza Strip] to organize themselves to defy and challenge the colonizing apartheid state, requires being guided by the principles of equality and social justice in fashioning their society, and not leaving it to the whims of the colonial power, the donors, or the market." He goes on to suggest possible campaigns, such as "legislation to establish a decent minimum wage, to provide formal protection to the unemployed, and to re-activate the social insurance law to be implemented in accordance to resources available with special attention to those with special needs. A strategy of widening the free provision of health care and education to cover all citizens would be an empowering strategy. Such a strategy should be based on an appreciation of women's role in the provision of care and right to participate in the paid labor force." ${ }^{\prime 6}$

Importantly, such principles are equally valid in the rest of the Arab world. The economic policies implemented by the PA today are not unique; they have been the standard fare of governments across the Middle East for at least two decades. Indeed, the uprisings that erupted across the region in 2011 were, in essence, a reflection of the effects of neoliberal transformations driven by autocratic rulers such as Hosni Mubarak and Zine al-Abidine Ben Ali with the strong support of the World Bank and other IFIs. ${ }^{65}$ Thus, any struggle against the economic policies of the PA aligns with similar movements across the broader region. The more such links are strengthened by building cross-border solidarity among grassroots workers, students, and farmer organizations, the more effective the resistance against the neoliberal development models can become. When empowerment incorporates a full understanding of Israeli power it acquires real meaning as development functions to struggle against and resist fragmentation, the legitimacy of or normalization with the Israeli state, and neoliberalism. As the history of the Palestinian people demonstrates, it is only mass, collective struggle that can confront Israeli power in all its manifestations and offer a glimpse of real human development.

\section{Acknowledgments}

This article is based on a talk given at "Development in the Occupied Palestinian Territory: Critical Reflections on Current Practices and Opening the Space for Debating Alternative Approaches," a workshop at the Center for Development Studies, Birzeit University, Birzeit, on 23 June 2011. The author thanks the organizers and participants of the workshop for valuable feedback and discussion.

\section{About the Author}

Adam Hanieh is a senior lecturer in development studies at School of Oriental and African Studies (SOAS), University of London. His most recent books include Lineages of Revolt: Issues of Contemporary Capitalism in the Middle East (Chicago: Haymarket Books, 2013) and Capitalism and Class in the Gulf Arab States (New York: Palgrave Macmillan, 2011). 


\section{ENDNOTES}

1 “Data: Net ODA Received per Capita (Current US\$)," World Bank, accessed 18 May 2016, http://data. worldbank.org/indicator/DT.ODA.ODAT.PC.ZS.

2 The Palestine Economic Policy Research Institute (MAS) found that the number of active NGOs in the oPt increased by 61.5\% in 2000-2007. See Mapping Palestinian Non-Governmental Organizations in the West Bank and the Gaza Strip (Jerusalem: Palestine Economic Policy Research Institute, 2007), http://www.palestineeconomy.ps/files/server/20151405162310-2.pdf. See also Jamil Hilal, "Civil Society in Palestine: A Literature Review," (paper presented at Research on Civil Society Organizations: Status and Prospects regional conference, Jordan, 26-28 January 2010).

3 Hilal, "Civil Society," p. 28. The author notes that Palestinian NGOs employed an average of twenty paid staff in 2007. Based on the 848,000-strong labor force and an estimated 2,100 NGOs operating inside the oPt, approximately 5 percent of the labor force was directly employed in the NGO sector.

4 "West Bank and Gaza," Government of Canada, modified 3 May 2016, http://www.acdi-cida.gc.ca/ acdi-cida/ACDI-CIDA.nsf/Eng/JUD-124144933-R9J.

5 Palestinian Central Bureau of Statistics, Palestine Statistical Yearbook 2015 [in Arabic] (Ramallah: Palestinian Central Bureau of Statistics, 2015), p. 123.

6 Sari Hanafi and Linda Tabar, The Emergence of a Palestinian Globalized Elite: Donors, International Organizations, and Local NGOs (Jerusalem: Institute of Jerusalem Studies, 2005).

7 See Sara Roy, The Gaza Strip: The Political Economy of De-development (Washington, DC: Institute for Palestine Studies, 2016), and Adel Samara, Epidemic of Globalization: Ventures in World Order, Arab Nation and Zionism (Glendale, CA: Palestine Research and Publishing Foundation, 2001).

8 For one example, see the April 2011 speech by former World Bank president Robert Zoellick: "Citizen Empowerment, Governance Key for Middle East-Zoellick," press release no. 2011/407/EXC, World Bank, 6 April 2011, http://go.worldbank.org/HOECHJLHMO.

9 For one example, see “GZ: Village and Neighborhood Development Project," World Bank, updated 16 August 2012, http://web.worldbank.org/external/projects/main?pagePK=64312881\&piPK=6430 2848\&theSitePK=40941\&Projectid=P104257.

10 Asala Research Study: Women's Economic Empowerment in the West Bank, Palestine (Ramallah: Asala, 2010), p. 9.

11 "Community Leadership and Empowerment Program," U.S. Middle East Partnership Initiative, accessed 3 June 2016, http://www.mepi-clep.com/about/.

12 “Children's Municipal Councils Give Children a Sense of Empowerment," UNICEF, 16 December 2004, http://www.unicef.org/infobycountry/oPt_24557.html.

13 "Ruwwad-Palestinian Youth Empowerment Program: West Bank and Gaza," USAID, http://www. equip123.net/webarticles/anmviewer.asp?a=639.

14 Giles Mohan and Kristian Stokke, "Participatory Development and Empowerment: The Dangers of Localism," Third World Quarterly 21, no. 2 (2000): p. 247.

15 An important marker of this transformation was the World Bank's 1997 World Development Report, which laid out the theoretical argument for what the bank termed an "effective state" and began the shift toward the good governance discourse that became so prominent through the 2000s.

16 Mohan and Stokke, "Participatory Development and Empowerment," p. 247.

17 The World Bank's good governance indicator (no. 4), for example, rates a country on "the ability of the government to . . . permit and promote private sector development." See "Worldwide Governance Indicators: Regulatory Quality," World Bank, accessed 3 June 2016, http://info. worldbank.org/governance/wgi/rq.pdf.

18 Aradhana Sharma, Logics of Empowerment: Development, Gender, and Governance in Neoliberal India (Minneapolis: University of Minnesota Press, 2008), p. xvi. 
19 Katie Willis, Theories and Practices of Development (London: Routledge, 2005), p. 97. Theoretically, the turn to NGOs was justified through their perceived connection to and accountability with local communities, their greater responsiveness to "community" needs, and their greater efficiency in project implementation (pp. 98-99). The New Policy Agenda-as Robinson described the development strategy embraced by the World Bank and other multilateral organizations in the early 1980s-drew a clear link between neoliberal economic policy and the focus on institutional governance. See Mark Robinson, "Governance, Democracy and Conditionality: NGOs and the New Policy Agenda," in Governance, Democracy and Conditionality: What Role for NGOs?, ed. Andrew Clayton (Oxford: INTRAC, 1994). In turn, this strategy ushered in NGOs as the new mode of service delivery. See David Hulme and Michael Edwards, eds., NGOs, States and Donors: Too Close for Comfort? (Basingstoke: Macmillan, 1997) for an early discussion of these themes.

20 Andrea Cornwall and Karen Brock, "What Do Buzzwords Do for Development Policy? A Critical Look at 'Participation, 'Empowerment' and 'Poverty Reduction,"' Third World Quarterly 26, no. 7 (2005): p. 1044. Cornwall and Brock go on to note that empowerment has thus lost "its original emphasis on building personal and collective power in the struggle for a more just and equitable world" (p. 1046).

21 Mohan and Stokke, "Participatory Development and Empowerment," p. 248.

22 Saraswati Raju, “Limited Options-Rethinking Women's Empowerment 'Projects' in Development Discourses: A Case from Rural India," Gender Technology and Development 9, no. 2 (July 2005): p. 255.

23 These definitions are drawn from Willis, Theories and Practices of Development (2005). For more discussion of these themes and their relationship to development theory and practice, see Jo Rowlands, "Empowerment Examined," Development in Practice 5, no. 2 (1995); Naila Kabeer, Reversed Realities: Gender Hierarchies in Development Thought (London: Verso, 1994); Steven Lukes, Power: A Radical View (London: Macmillan, 1974); Zoë Oxaal and Sally Baden, Gender and Empowerment: Definitions, Approaches and Implications for Policy; Briefing Prepared for the Swedish International Development Cooperation Agency (Sida), Bridge report no. 40, (Brighton, UK: Institute for Development Studies, University of Sussex, 1997).

24 Willis, Theories and Practices of Development, p. 113.

25 Willis, Theories and Practices of Development, p. 113.

26 This version of power echoes Gramsci's observation about ruling class hegemony. In any society, the ruling elite-what Gramsci described as the historic bloc-functions not solely through the naked exercise of power, but also by projecting its interests as coincident with those of the entire society.

27 Willis, Theories and Practices of Development, p. 113.

28 Frantz Fanon, Black Skin, White Masks (New York: Grove, 1967), p. 18.

29 Parts of the section that follows draw on chapter 5 of Adam Hanieh, Lineages of Revolt: Issues of Contemporary Capitalism in the Middle East (Chicago: Haymarket, 2013).

30 Hanieh, Lineages of Revolt, p. 120.

31 Hanieh, Lineages of Revolt, p. 120.

32 Willis, Theories and Practices of Development, p. 113.

33 See Hanieh, Lineages of Revolt, pp. 101-7 for a full discussion of this process.

34 The failed "Village Leagues" of the 1970s were another example of this.

35 Omar Suliman-Jabary Salamanca, "Fabric of Life: The Infrastructure of Settler Colonialism and Uneven Development in Palestine," (PhD diss., Ghent University, 2014).

36 Leila Farsakh, Palestinian Labour Migration to Israel: Labour, Land and Occupation (London: Routledge, 2005).

37 Shir Hever, The Political Economy of Israel's Occupation: Repression beyond Exploitation (London: Pluto Press, 2010), p. 36.

38 Hever, The Political Economy of Israel's Occupation, pp. 42-45. 
Development as Struggle: Confronting the Reality of Power in Palestine

39 World Bank, The Underpinnings of the Future Palestinian State: Sustainable Growth and Institutions; Economic Monitoring Report to the Ad Hoc Liaison Committee (Washington, DC: World Bank, 21 September 2010), p. 30. Available at https://unispal.un.org/DPA/DPR/UNISPAL.NSF/85255db 80047 0aa485255d8b004e349a/d2dfb1a6dc7c7bc1852577a100494830?OpenDocument.

40 Hanieh, Lineages of Revolt, p. 118.

41 World Bank, Building the Palestinian State: Sustaining Growth, Institutions, and Service Delivery; Economic Monitoring Report to the Ad Hoc Liaison Committee (Washington, DC: World Bank, 13 April 2011), p. 16. Available at http://www.lacs.ps/documentsShow.aspx?ATT_ID=3834.

42 World Bank Technical Team, The "Door to Door" Movement of Goods (Washington, DC: World Bank, 5 July 2005), p. 6; Stop the Wall, Development or Normalization? A Critique of West Bank Development Approaches and Projects (Palestinian Grassroots Anti Apartheid Wall Campaign, n.d.), http://www. stopthewall.org/downloads/PRDPcritique.pdf. See below for further examples on the process of incorporating the occupation into development practice.

43 It should be noted that the initial laboratory of neoliberalism was Latin America, specifically the Pinochet military dictatorship that ruled Chile from 1973-90.

44 See Alfredo Saad-Filho and Deborah Johnston, eds., Neoliberalism: A Critical Reader (London: Pluto Press, 2005).

45 See Hanieh, Lineages of Revolt, chap. 3 for an account of neoliberalism in the Middle East.

46 Palestinian National Authority, Building a Palestinian State: Towards Peace and Prosperity (Paris: Palestinian National Authority, 17 December 2007), p. 18. Available at https://unispal.un.org/pdfs/ PRDPFinal.pdf.

47 Adam Hanieh, "Palestine in the Middle East: Opposing Neoliberalism and US Power," MRzine, 19 July 2008, http://www.monthlyreview.org/mrzine; Hanieh, Lineages of Revolt; Raja Khalidi and Sobhi Samour, "Neoliberalism as Liberation: The Statehood Program and the Remaking of the Palestinian National Movement," Journal of Palestine Studies 40, no. 2 (Winter 2011): pp. 6-25.

48 Hanieh, Lineages of Revolt, p. 118.

49 "West Bank and Gaza: Trust Fund Details," World Bank, accessed 5 December 2012, http://go. worldbank.org/JJUOZ8HYIO.

50 See Hanieh, Lineages of Revolt, pp. 47-73 for a full discussion of this issue in the context of the Middle East.

51 World Bank, Building the Palestinian State, p. 13.

52 Later on in the report, the World Bank outlines what this means: "The policy must be set to facilitate trade, not to raise government revenues, redistribute resources, or favor one sector over another. Tariffs must be low and there should be no quantitative restrictions or other nontariff barriers to trade. Given the vital importance of trade, the government of a future Palestinian state might consider eventually moving to a policy of free trade as Estonia, Hong Kong, and Singapore have done." World Bank, Building the Palestinian State, p. 14.

53 Mohan and Stokke, "Participatory Development and Empowerment," p. 248.

54 World Bank, Building the Palestinian State, p. 13.

55 Khalidi and Samour, "Neoliberalism as Liberation."

56 Hilal documents, "The richest $10 \%$ of households consumed $26.6 \%$ of total monthly consumption in 2007 compared to $20.7 \%$ in 2006. In the WB, the increase was from $21.6 \%$ in 2006 to $25.8 \%$ in 2007 , and in GS it jumped from $17.2 \%$ in 2006 to $31.8 \%$ in 2007. In other words the richest $10 \%$ of households in the WBGS consumed in 2007 eight times more than the poorest $10 \%$ of the households." Jamil Hilal, The Pauperization of Women, Men and Children in the West Bank and Gaza Strip (Birzeit: Institute for Women's Studies, Birzeit University, 2010), p. 2.

57 "Statistics: Monthly Statistical Bulletin, Table 24: Distribution of Loans by Sector," Palestine Monetary Authority (PMA), November 2015, http://www.pma.ps/en-us/statistics/monthlystatisticalbulletin. aspx. 
58 PMA, 2015.

59 "Table 1: Percentage Distribution of Persons Aged 15 Years and Above from Palestine by Region and Labour Force Status, 2000-2014," in Palestinian Central Bureau of Statistics, Annual Report (Ramallah: State of Palestine, 2014), p. 57; Palestinian Central Bureau of Statistics, Palestine in Figures, 2014 (Ramallah: State of Palestine, 2015), p. 25.

60 See Anne Showstack Sassoon, "Globalisation, Hegemony and Passive Revolution," New Political Economy 6, no. 1 (2001); Gérard Duménil and Dominique Lévy, "Costs and Benefits of Neoliberalism: A Class Analysis," Review of International Political Economy 8, no. 4 (2001): pp. 578-607; and David Harvey, A Brief History of Neoliberalism (Oxford: Oxford University Press, 2005), for various perspectives on neoliberalism, finance, and political power.

61 Susan Christopherson, Ron Martin, and Jane Pollard, "Financialisation: Roots and Repercussions," Cambridge Journal of Regions, Economy and Society 6, no. 3 (2013): pp. 351-57.

62 Costas Lapavitsas makes this point strongly in his theorization of financialization. See Costas Lapavitsas, "Financialised Capitalism: Crisis and Financial Expropriation," Historical Materialism 17, no. 2 (2009): pp. 114-48.

63 For further discussion of how finance-led neoliberalism has transformed forms of social solidarity and political struggle, see Greg Albo, Sam Gindin, and Leo Panitch, In and Out of Crisis: The Global Financial Meltdown and Left Alternatives (Oakland, CA: PM Press, 2010).

64 Hilal, The Pauperization of Women, p. 12.

65 See Hanieh, Lineages of Revolt. 